\title{
SISTEM OPERASI BANK SYARIAH DAN PENYAJIAN DALAM AKUNTANSI SYARIAH
}

\author{
Ridwan $^{1}$
}

\begin{abstract}
Abstrak
Bank syariah merupakan lembaga keuangan yang beroperasi dengan tidak mengandalkan pada bunga yang berdasarkan asas-asas kemitraan, keadilan, transparan, dan universal yang di implementasikan dalam bentuk pelarangan riba dalam berbagai bentuknya dimana usaha pokoknya memberikan pembiayaan dan jasa-jasa lainnya dalam lalu lintas pembayaran serta peredaran uang yang operasinya tidak hanya berlaku untuk orang islam saja tetapi juga untuk seluruh lapisan masyarakat sesuai dengan prinsip syariah.

Bank syariah bertujuan mengadakan kegiatan ekonomi ummat secara Islam, khususnya yang berhubungan dengan kegiatan perbankan agar terhindar dari praktek-praktek yang dapat menimbulkan dampak negatif terhadap kehidupan ekonomi rakyat.

Hubungan ekonomi berdasarkan islam ditentukan oleh hubungan akad yang terdiri dari lima konsep dasar akad. Bersumber dari kelima konsep dasar inilah dapat ditemukan produk-produk lembaga keuangan bank syariah. Kelima konsep tersebut adalah (1) system simpanan, (2) bagi hasil, (3) margin keuntungan atau jual beli, (4) sewa, (5) feeljasa. Dana yang dihimpun melalui produk penghimpunan dana yang terdiri dari prinsip wadi'ah dan prinsip mudharabah, sedangkan dana disalurkan melalui produk yang terdiri murabahah, bai'As-salam, al-istishnana, musyarakah.

Penyajian dalam laporan akuntansi bank syariah telah diatur dengan Pedoman Standar Akuntansi Keuangan (PSAK) dan Pedoman akuntansi Perbankan Syariah Indonesia (PAPSI), yang salah satu penyajiannnya adalah Laporan keuangan yang menggambarkan fungsi bank islam sebagai investor serta hak dan kewajibannya.
\end{abstract}

Kata kunci: bank syariah, produk syariah, laporan keuangan syariah

\footnotetext{
${ }^{1}$ Penulis adalah dosen tetap pada Jurusan Syariah STAIN Manado
} 


\section{A. Pendahuluan}

Dalam konteks pembangunan ekonomi ummat, keberadaan dan kehadiran lembaga bisnis, seperti lembaga keuangan syariah adalah mutlak adanya. Sebab perbankan bertindak sebagai perantara antara unit penawaran dengan unit permintaan ${ }^{2}$. Keberadaan bank syariah sebagai organisasi yang relatif baru menimbulkan tantangan besar. Para pakar syariah dan akuntansi harus mencari pedoman yang digunakan untuk berperilaku dalam segala aspek kehidupan termasuk bisnis perbankan yang tidak terlepas dari ikatan etika syariah dalam melayani masyarakat di sekitarnya sehingga harus dapat menyajikan system operasi yang cukup, dapat dipercaya, dan relevan bagi para penggunanya, namun tetap dalam konteks syariah ${ }^{3}$.

Salah satu prasyarat pengembangan kepercayaan itu adalah ketersediaan informasi yang meyakinkan nasabah terhadap kemampuan bank Islam dalam mencapai tujuannya. Diantara sumber-sumber informasi yang penting adalah sistem informasi produk dan penyajian akuntansi dari bank syariah yang disiapkan sesuai dengan standar yang dapat diterapkan pada bank Islam. Bank syariah memiliki peran sebagai lembaga perantara antara unit-unit ekonomi yang mengalami kelebihan dana dengan unit-unit yang lain yang mengalami kekurangan dana, melalui produk bank syariah kelebihan tersebut dapat disalurkan kepada pihak-pihak yang memerlukan sehingga memberikan manfaat kepada kedua belah pihak. Kualitas bank syariah sebagai lembaga perantara ditentukan kemampuan manajemen dalam operasinya serta penyajian dalam akuntansinya yang tidak bertentangan dengan prinsip-prinsip muamalah Islam.

Hubungan antara bank dengan nasabahnya bukan hubungan debitur dan kreditur, melainkan hubungan kemitraan dana (partnership) antara penyandang dana

\footnotetext{
${ }^{2}$ Muhamad, Lembaga Keuangan Umat Kontemporer, dalam Muhammad, Pengantar Akuntuntasi Syariah edisi 2, (Yogyakarta: Penerbit Salemba Empat, 2005), h. 2.

${ }^{3}$ Ali, Hasyim, Manajemen Bank Islam, (Jakarta: Radar Jaya Offset, 1992), hlm. 12.
} 
(shohibul maal) dengan pengelola dana (mudharib). Oleh karena itu, tingkat laba bank syariah tidak saja berpengaruh terhadap bagi hasil yang dapat diberikan kepada nasabah penyimpan dana. Hubungan ini merupakan bagian yang khas dari proses berjalannya mekanisme bank syariah ${ }^{4}$.

Bisnis secara syariah adalah aktivitas bisnis yang syarat dan berorientasi pada nilai. Dengan demikian pelaporan atas aktivitas dan hasilnya harus dilaporkan atau dilakukan berdasarkan prinsip-prinsip syariah. Untuk mencapai tegaknya sasaran pokok tersebut, maka perlu penyiapan sistem akuntansi untuk praktik bisnis berdasarkan syariah.

\section{B. Pembahasan}

\section{a. Pengertian dan Konsep Bank Syariah}

Bank syariah adalah lembaga keuangan yang usaha pokoknya memberikan kredit dan jasa-jasa lain dalam lalu lintas pembayaran serta peredaran uang yang beroperasi dengan prinsip prinsip syariah ${ }^{5}$. Pendapat lain bahwa bank syariah adalah lembaga keuangan yang beroperasi dengan tidak mengandalkan pada bunga yang usaha pokoknya memberikan pembiayaan dan jasa-jasa lainnya dalam lalu lintas pembayaran serta peredaran uang yang pengoperasiannya sesuai dengan prinsip syariah $^{6}$.

Bank Syariah adalah Bank yang berdasarkan asas-asas kemitraan, keadilan, transparan, dan universal yang di implementasikan dalam bentuk pelarangan riba dalam berbagai bentuknya, Bank Syariah tidak mengenal konsep nilai, waktu, dan ruang konsep uang di Bank Syariah adalah sebagai alat tukar, bukan sebagai

${ }^{4}$ Antonio, Syafii,M., Bank Syariah. (Jakarta: PT Serambi IImu Persada, 2002), hlm. 31.

${ }^{5}$ Sudarsono, H., Bank dan lembaga Keuangan Syariah Deskrpsi dan Ilustrasi, (Yogyakarta: Penerbit Ekonisia, 2004), hlm. 56.

6 Donna, Duddy Roesmara, Variabel-variabel yang Mempengaruhi Pembiayaan Perbankan Syariah di Indonesia, (penerbit: Yogyakart, FE UGM, 2006) Tesis. 
komoditas, Bank Syariah tidak melakukan kegiatan yang bersifat perjudian (maisyri) transaksi yang tidak jelas (gharar) tidak hanya berlaku untuk orang islam saja tetapi juga untuk seluruh lapisan masyarakat.

Lembaga bisnis Islami merupakan salah satu instrumen yang digunakan untuk menegakkan aturan-aturan ekonomi Islami. Sebagai bagian dari sistem ekonomi, lembaga tersebut merupakan bagian dari keseluruhan sistem sosial. Oleh karenanya, keberadaannya harus dipandang dalam konteks keberadaan masyarakat, serta nilai-nilai yang berlaku dalam masyarakat ${ }^{7}$. Lembaga Keuangan tersebut harus beroperasi secara ketat berdasarkan prinsip-prinsip syariah. Prinsip ini sangat berbeda dengan prinsip yang dianut oleh lembaga keuangan non syariah. Adapun prinsip-prinsip yang dirujuk adalah ${ }^{8}$ :

1. Larangan menerapkan bunga pada semua bentuk dan jenis transaksi.

2. Menjalankan aktivitas bisnis dan perdagangan berdasarkan pada kewajaran dan keuntungan yang halal.

3. Mengeluarkan zakat dari hasil kegiatannya.

4. Larangan menjalankan monopoli; dan

5. Bekerjasama dalam membangun masyarakat, melalui aktivitas bisnis dan perdagangan yang tidak dilarang oleh Islam.

Hubungan ekonomi berdasarkan islam ditentukan oleh hubungan akad yang terdiri dari lima konsep dasar akad. Bersumber dari kelima konsep dasar inilah dapat ditemukan produk-produk lembaga keuangan bank syariah. Kelima konsep tersebut adalah (1) system simpanan, (2) bagi hasil, (3) margin keuntungan atau jual beli, (4) sewa, (5) fee/jasa ${ }^{9}$ :

${ }^{7}$ Muhammad, Pengantar Akuntansi Syariah, (Jakarta: Salemba Empat, Edisi 2, 2005), h. 173.

${ }^{8}$ Muhammad, Lembaga Keuangan Umat Kontemporer, Yogyakarta: Penerbit UII Press, 2000), h. 25.

${ }^{9}$ Muhammad, system dan Prosedur Bank Syariah, (Yogyakarta: Penerbit UII Press, 2000), dalam, Muhammad, Pengantar Akuntansi Syariah, (Jakarta: Salemba Empat, 2005), h. $175-177$. 
1. Prinsip simpanan murni (al-wadi'ah), merupakan fasilitas yang diberikan oleh bank islam untuk memberikan kesempatan kepada pihak yang berlebhan dana untuk menyimpan dananya dalam bentuk al-wadi'ah.

2. Bagi hasil, (syirkah), adalah suatu sistem yang meliputi tata cara pembagian hasil usaha antara penyedia dana dengan pengelola dana. Pembagian hasil usaha inilah antara bank dengan penyimpan dana, maupun antara bank dengan nasabah penerima dana.

3. Prinsip jual beli (at-tijarah), merupakan suatu sistem yang menerapkan tata cara jual beli, dimana bank akan membeli terlebih dahulu barang yang dibutuhkan atau mengangkat nasabah sebagai agen bank melakukan pembelian barang atas nama bank kemudian bank menjual barang tersebut kepada nasabah dengan $\mathrm{k}$ dapat harga sejumlah harga beli ditambah keuntungan (margin).

4. Prinsip sewa (al-Ijarah), terbagi dua jenis: (a) Ijarah sewa murni dalam teknis perbankan, bank dapat membeli dahulu equipment yang dibutuhkan nasabah kemudian menyewakan kepada nasabah. (b) Ijarah bintahiyah bittamlik, merupakan penggabungan sewa dan beli, dimana si penyewa mempunyai hak untuk memiliki barang pada akhir masa sewa.

5. Prinsip fee/jasa (al-ajr wal umulah), meliputi seluruh layanan non pembiayaan yang diberikan bank, misalnya kliring, inkaso, jasa transper dan lain-lain.

\section{b. Fungsi Bank Syariah}

Fungsi bank syariah yang diantaranya tercantum dalam pembukaan standar akuntansi yang dikeluarkan oleh AAOIFI (Accounting and Auditing Organization for Islamic Financial Institution), sebagai berikut:

1. Manajer investasi, bank syariah dapat mengelola investasi dana nasabah.

2. Investor, bank syariah dapat menginvestasikan dana yang dimilikinya maupun dana nasabah yang dipercayakan kepadanya.

3. Penyedia jasa keuangan dan lalu lintas pembayaran, bank syariah dapat melakukan kegiatan-kegiatan jasa-jasa layanan perbankan sebagaimana lazimnya. 
4. Pelaksanaan kegiatan sosial, sebagai ciri yang melekat pada entitas keuangan syariah, bank Islam juga memiliki kewajiban untuk mengeluarkan dan mengelolah zakat serta dana-dana sosial lainnya ${ }^{10}$.

\section{c. Produk Penghimpunan dana Bank Syariah}

\section{Wadi'ah}

Wadi'ah dapat diartikan sebagai titipan murni dari satu pihak ke pihak lain, sipenitip menghendaki ${ }^{11}$.

Landasan hukum: Al-Quran:

Sesungguhnya Allah menyuruh kamu untuk menyampaikan amanat (titipan), kepada yang berhak menerimanya....(an-Nisaa: 58).

.....jika sebagian kamu mempercayai sebagian yang lain, hendaklah yang dipercaya itu menunaikan amanat (utangnya) dan hendaklah ia bertakwa kepada allah Tuhannya... (Al-Baqarah: 283) ${ }^{12}$.

Ketentuan perbankan dalam akad wadi' ${ }^{13}{ }^{13}$ :

a. Keuntungan atau kerugian dari penyaluran dana menjadi milik atau ditanggung bank, sedang pemilik dana tidak dijanjikan dan tidak menanggung kerugian

b. Bank harus membuka akad pembukaan rekening yang izinya mencakup penyaluran dana yang disimpan dan persyaratan lain yang disepakati selama tidak bertentangan dengan prinsip syariah

c. Terhadap pembukaan rekening ini bank dapat mengenakan pengganti biaya administrasi untuk sekedar meunupi biaya yang benar-benar terjadi

${ }^{10}$ Muhammad Syafii Antonio, Pengenalan Umum Bank Syariah. (Jakarta: Tazkia Institut bekerja sama dengan Bank Indonesia, 1999).

${ }^{11}$ Sayyid Sabiq, Fighus Sunnah, (Beirut: Darul Kitab al-Arabi, cetakan 8, 1987), h. 3 , dalam Muhammad Syafii Antonio, Bank Syariah dari Teori ke Praktitik (Jakarta: Gema Insani, 2001), h. 85.

${ }^{12}$ Muhammad Syafii Antonio. Op. cit, h. 85.

${ }^{13}$ Anonimus, Prodak-prodak Bank Islam, (Jakarta: Karim Consulting bekerjasama dengan Bank Indonesia, 20020, dalam Muhammad Syafii Antonio, Bank Syariah dari Teori ke Praktitik (Jakarta: Gema Insani, 2001), h. 178. 
d. Ketetentuan lain yang berkaitan dengan rekening giro dan tabungan tetap berlaku selama tidak bertentangan dengan prinsip syariah.

Aplikasi perbankan wadi'ah dapat digambarkan dalam skema berikut ini:

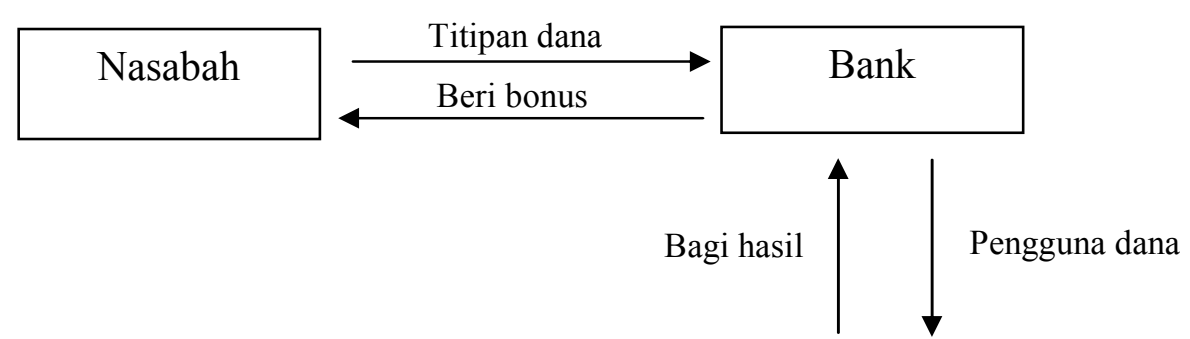

Dunia usaha

\section{Mudharabah}

Mudharabah adalah akad kerjasama usaha antara dua pihak dimana pihak pertama (shahibul maal) menyediakan seluruh modal, sedangkan pihak lainnya menjadi pengelola. Keuntungan usaha secara mudharabah dibagi menurut kesepakatan yang dituangkan dalam kontrak, sedangkan apabila rugi ditanggung oleh pemilik modal selama kerugian itu bukan akibat kelalaian si pengelola. Seandainya kerugian itu diakibatkan karena kecurangan atau kelalaian si pengelola, si pengelola harus bertarnggung jawab atas kerugian tersebut ${ }^{14}$. Rukun mudharabah adalah: (a) ada pemilik dana, ( b) ada usaha yang akan dibagi hasilkan,(c) ada nisbah, (d) ada ijab kabul $^{15}$.

Landasan hukum: Al-Qur'an:

......dan jika dari orang-orang yang berjalan di muka bumi mencari karunia Allah SWT (QS. al-Muzaammil: 20).

${ }^{14}$ Muhammad Syafii Antonio, Bank Syariah dari Teori ke Praktitik (Jakarta: Gema Insani, 2001), h. 95.

${ }^{15}$ Muhammad, op. cit, h. 178. 
Apabila telah ditunaikan shalat maka bertebaranlah kamu di muka bumi dan carilah karunia Allah SWT (QS. al-]umuah: 10) ${ }^{16}$.

Ketentuan perbankan dalam akad mudharabah:

a. Jumlah modal yang diserahkan kepada nasabah selaku pengeluaran modal harus diserahkan tunai, dapat berupa uang atau barang yang dinyatakan nilainya dalam satuan uang. Apabila modal diserahkan secara bertahap, harus jelas tahapannya d disepakati bersama.

b. Hasil pengelolaan modal pembiayaan mudharabah dap diperhitungkan dengan dua cara :

1) Hasil usaha dibagi sesuai dengan persetujuan dalam akad, pada setiap bulan atau waktu yang telah disepakati. Bank selaku pemilik modal menanggung seluruh kerugian kecuali akibat kelalaian dan penyimpanan pihak nasabah, seperti pens lowongan, kecurangan, dan penyalahgunaan dana.

2) Bank berhak melakukan pengawasan terhadap pekerjaan namun tidak berhak mencampuri urusan pekerjaan/usaha nasabah ${ }^{17}$

Aplikasi perbankan mudharabah dapat digambarkan dalam skema berikut ini:

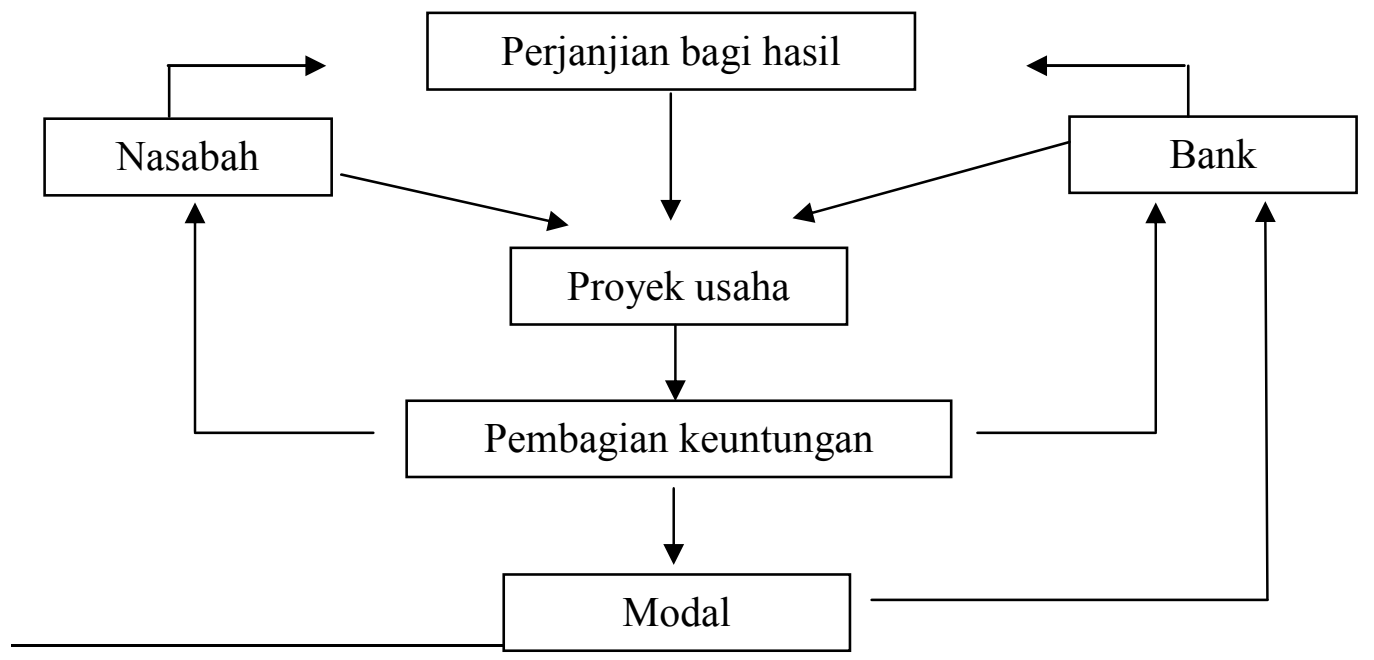

${ }^{16}$ Muhammad Syafii Antonio, op. cit, h. 95.

${ }^{17}$ Muhammad, op. cit, h. 186. 


\section{d. Produk Penyaluran Dana Bank Syariah}

\section{Murabahah}

Murabahah adalah jual-beli barang pada harga asal dengan tambahan keuntungan yang disepakati antara pihak bank dan nasabah ${ }^{18}$. Dalam murabahah, penjual harus memberitahu harga produk yang ia beli dan menentukan tingkat keuntungan sebagai tambahannya.

Landasan hukum : Al-Qur'an:

Allah telah menghalalkan jual-beli dan mengharamkan riba (QS. A1

Baqarah: 275) ${ }^{19}$

Ketentuan perbankan dalam akad murabahah:

a. Penjual member tahu biaya modal kepada nasabah

b. Kontrak pertama harus sah sesuai dengan rukun yang ditetapkan

c. Kontrak harus bebas dari riba

d. Penjual harus menjelaskan kepada pembeli bila terjadi cacat atas barang sesudah pembelian

e. Penjual harus menyampaikan semua hal yang berkaitan dengan pembelian, misalnya jika pembelian dilakukan secara utang ${ }^{20}$

Aplikasi perbankan al-murabahah dapat digambarkan dalam skema berikut ini:

${ }^{18}$ Muhammad Ibn Ahmad Ibnu Rusyd, Bidayatul Nutjihad wa Nihayatul Mugtashid Darul Qalam, dalam Muhammad Syaii Antoni, Bank Syariah dari Teori ke Praktik, (Jakarta: Penerbit: Gema Insani, 2001), h. 101.

${ }^{19}$ Muhammad Syafii Antonio, op. cit, h. 102.

${ }^{20}$ Muhammad Syafii Antonio, op.cit, h. 90 


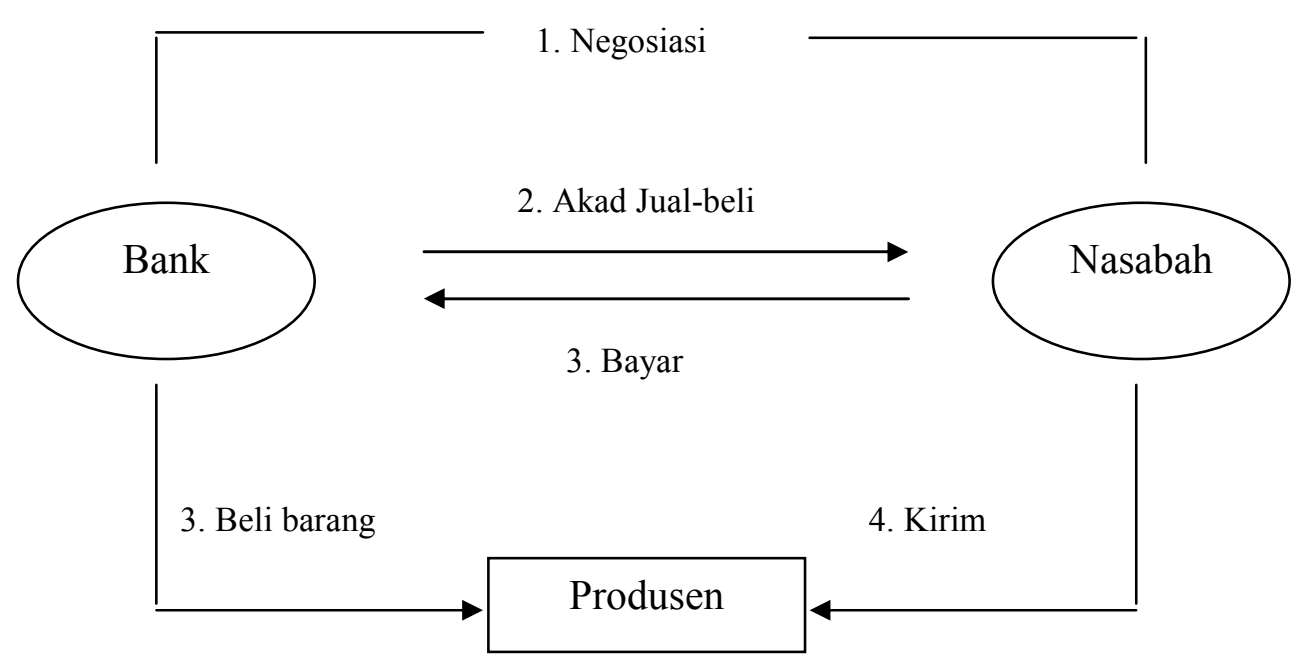

\section{Bai' As-Salam}

Dalam pengertian yang sederhana, salam berarti pembelian barang yang diserahkan dikemudian hari, sedangkan pembayaran dilakukan lebih dahulu $(\text { dimuka })^{21}$.

Landasan hukum, Al-Qur'an:

Hai orang-orang yang beriman, apabila kamu bermuamalah tidak secara tunai untuk waktu yang ditentukan, hendaklah kamu menuliskannya.

(Al-Baqarah: 283) ${ }^{22}$.

Ketentuan perbankan dalam akad as-salam:

1. Pembelian hasil produksi harus diketahui spesifikasinya secara jelas, seperti, ukuran, mutu dan jumlahnya

2. Apabila hasil produksi diterima cacat atau tidak sesuai dengan akad nasabah harus bertanggung jawab

3. Mengingat bank tidak menjadikan barang yang dibeli atau dipesannya sebagai persediaan, maka bank dimungkinkan melakukan akad salam pada pihak ketiga (pembeli).

${ }^{21}$ Ibid, h. 108.

${ }^{22}$ Muhammad Syafii Antonio, op. cit, h. 108. 
Aplikasi perbankan As-Salam dapat digambarkan dalam skema berikut ini:

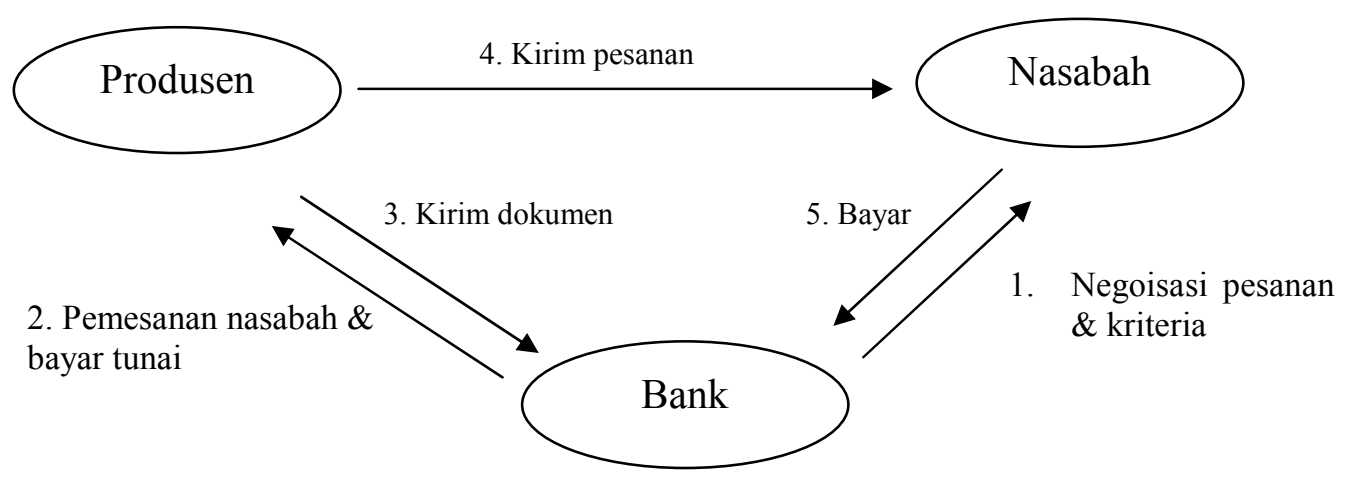

\section{Al-Istishana}

Istishana jual beli seperti akad salam namun pembayarannya dilakukan oleh bank dalam beberapa kali pembayaran. Istishana diterapkan pada pembiayaan manufaktur dan konstruksi.

Landasan hukum, mengingat al-istishana merupakan lanjutan dari as-salam maka secara umum landasan syariah yang berlaku pada as-salam juga berlaku pada al-istishana.

Ketentuan perbankan dalam akad al-istihana:

1. Spesifikasi barang pesanan harus jelas, seperti jenis, macam, ukuran, dan jumlah.

2. Harga jual telah disepakati tercantum dalam akad istishna dan tidak boleh berubah selama berlakunya akad.

3. Jika terjadi perubahan dan kriteria pesanan dan terjadi perubahan harga setelah akad ditandatangani, maka seluruh biaya tambahan tetap ditanggung nasabah ${ }^{23}$.

${ }^{23}$ Muhammad, op. cit, h. 182-183. 
Aplikasi perbankan Al-istishana dapat digambarkan dalam skema berikut ini:

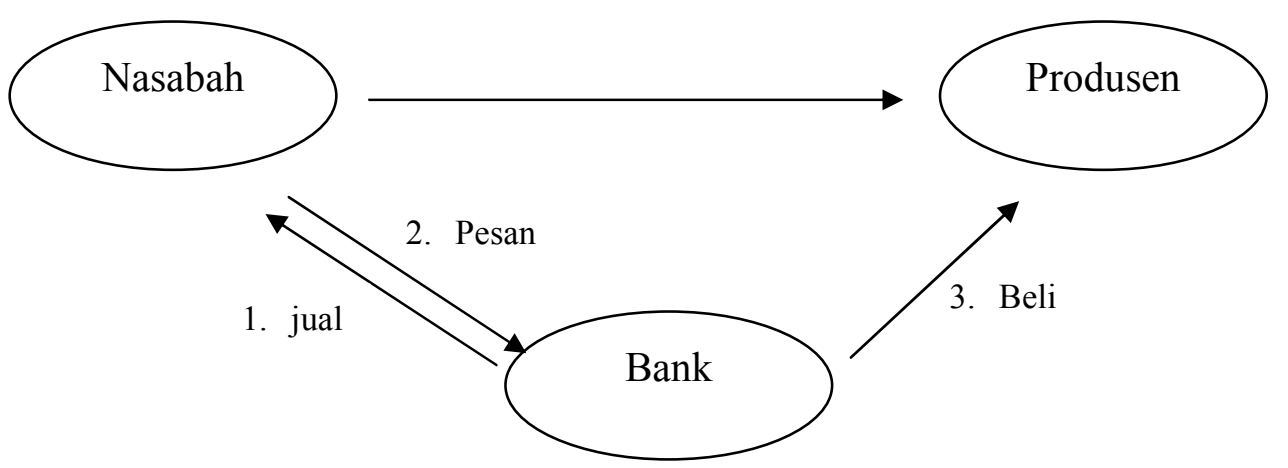

\section{Musyarakah}

Musyarakah adalah kerjasama antara kedua pihak atau lebih untuk suatu usaha tertentu dimana masing-masing pihak memberikan kontribusi dana dengan keuntungan dan risiko akan ditanggung bersama sesuai dengan kesepakatan ${ }^{24}$.

Musyarakah ada dua jenis, yaitu musyarakah pemilikan dan musyarakah adad (kontrak). Musyarakah pemilikan tercipta karena warisan wasiat atau kondisi lainnya yang berakibat pemilikan satu aset oleh dua orang atau lebih. Sedangkan musyarakah akad tercipta dengan kesepakatan dimana dua orang atau lebih setuju bahwa tiap orang dari mereka memberikan modal musyarakah dan berbagi keuntungan dan kerugian $^{25}$.

Landasan hukum: Al-Quran:

Maka mereka berserikat pada sepertiga (QS. an-Nisaa: 12),

.....dan, sesungguhnya kebanyakan dari orang-orang yang berserikat itu sebagian mereka berbuat dzalim kepada sebagian yang lain kecuali orang yang beriman dan mengerjakan amal saleh (QS. Shaad: 24$)^{26}$.

Ketentuan perbankan dalam akad musyarakah:

a. Semua modal disatukan untuk dijadikan modal proyek nusyarakah dan dikelola bersama-sama.

${ }^{24}$ Ibid, h. 102.

${ }^{25} \mathrm{Ibid}$, h. $91-92$.

${ }^{26}$ Muhammad Syafii Antonio, op. cit, h. 91. 
b. Setiap pemilik modal berhak turut serta dalam menetukan kebijakan usaha yang dijalankan oleh pelaksana proyek.

c. Pemilik modal dipercaya untuk menjalankan proyek musyarakah tidak boleh melakukan tindakan, seperti:

- Menggabingkan dana proyek dengan harta pribadi

- Menjalankan proyek musyarakah dengan pihak lain tanpa izin pemilik modal lainnya

- Member pinjaman kepada pihak lain

- Setiap pemilik modal dianggap mengakhiri kerjasama apabila: menarik diri dari perserikatan, meninggal dunia, menjadi tidak cakap hukum.

- Biaya yang timbul dalam pelaksanaan proyek dan jangka waktu proyek harus diketahui bersama

- Proyek yang akan dijalankan harus disebutkan dalam akad ${ }^{27}$.

Aplikasi perbankan al-musyarakah dapat digambarkan dalam skema berikut ini:

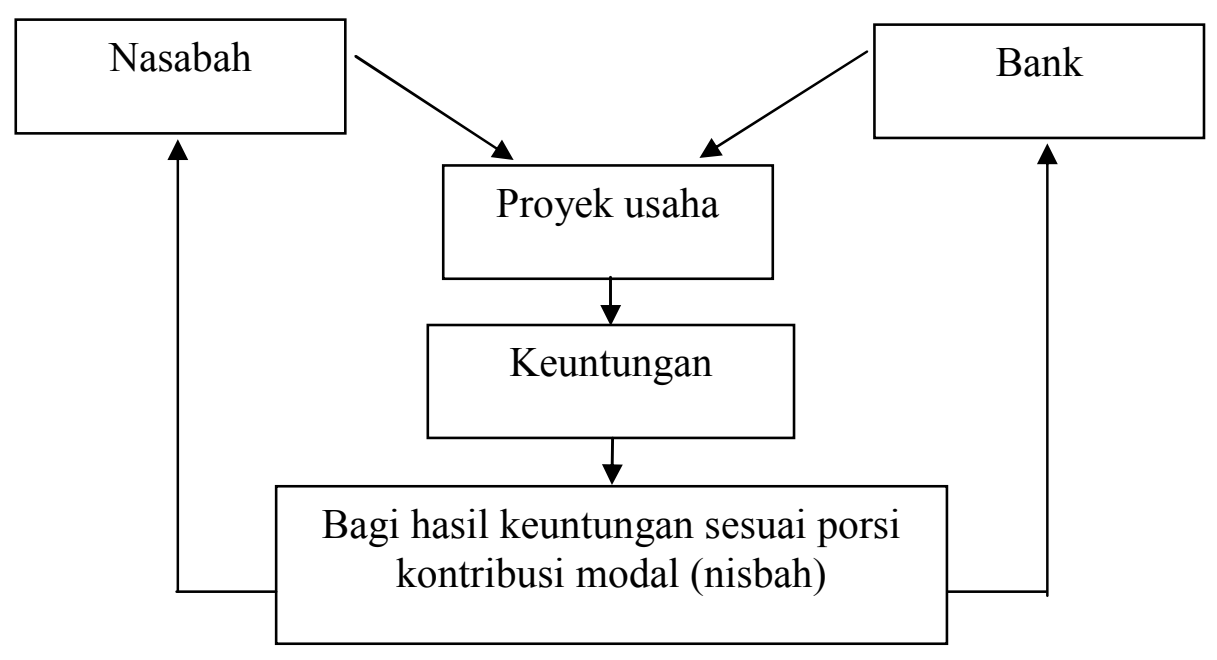

${ }^{27}$ Muhammad, op. cit, h. 184. 


\section{e. Prinsip Umum Akuntansi Syariah}

Nilai pertanggungjawaban, keadilan dan kebenaran selalu melekat dalam sistem akuntasi syariah. Ketiga nilai tersebut tentu saja telah menjadi prinsip dasar yang universal dalam operasional akuntansi syariah. Berikt uraian ketiga prinsip yang terdapat dalam surat Al-Baqarah: 282.

1. Prinsip pertanggung jawaban

Pertanggung jawaban selalu berkaitan dengan konsep amanah yang banyak dijelaskan danlam ayat al-Quran. Implikanasi dalam bisnis dan akuntansi adalah bahwa individu yang terlibat dalam praktik bisnis harus selalu melakukan pertanggungjawaban apa yang telah diamanatkan dan diperbuat kepada pihakpihak yang terkait. Wujud dalam pertanggungjawa biasanya dalam bentuk laporan akuntansi.

\section{Prinsip keadilan}

Jika ditafsirkan lebih lanjut, ayat 282 surat Al-Baqarah mengandung prinsip keadilan dalam melakukan transaksi. Prinsip keadilan ini tidak saja merupaka nilai yang sangat penting dalam etika kehidupan social dan bisnis, tetapi juga merupakan nilai yang secara inheran melekat dalam pitrah manusia.

3. Prinsip kebenaran

Kebenaran akan dapat menciptakan keadilan dalam mengakui, mengukur, dan melaporkan transaksi-transaksi ekonomi, kebenaran dalam Al-quran tidak dapat diperbolehkan untuk dicampur adukkan dengan kebathilan.

\section{f. Penyajian dalam Akuntansi Bank Syariah}

Penyajian dalam laporan akuntansi bank syariah telah diatur dengan Pedoman Standar Akuntansi Keuangan (PSAK) dan Pedoman akuntansi Perbankan Syariah Indonesia (PAPSI). Oleh karena itu, laporan keuangan harus mampu menfasilitasi semua pihak yang terikat dengan bank syariah.

Bank syariah secara umum dalam melakukan penyusunan laporan keuangan melalui beberapa tahapan antara lain:

1. Bukti transaksi 
Bukti transaksi merupakan kepastian keabsahan transaksi yang dicatat dan sebagai rujukan apabila terjadi masalah dikemudian hari

2. Jurnal

Cara pencatatan ayat jurnal dilakukan dengan sistem akuntansi berpasangan (double entry accounting system).

3. Buku besar

Buku besar data pindahan dari jurnal ke dalam akun maing-masing (posting). Adapun langkah-langkah posting adalah sebagai berikut :

a. Pindahkan tanggal yang terdapat dalam jurnal ke dalam akun yang bersangkutan.

b. Pindahkan jumlah yang didebit dan atau dikredit dalam jurnal ke dalam debit dan atau kredit perkiraan buku besar.

c. Catat kode dan nomor halaman jurnal ke dalam kolom "ref" di akun buku besar (cross indexing).

d. Jumlahkan sisi debit dan atau kredit kemudian cari selisih jumlah debit dan atau kredit tersebut untuk menentukan saldo akhirnya.

4. Neraca saldo

Neraca saldo adalah pengelompokan akun-akun buku besar berdasarkan saldo debit dan saldo kreditnya, sehingga jumlah saldo yang ada di sisi debit sama dengan jumlah yang ada di sisi kredit.

5. Jurnal Penyesuaian

Jurnal penyesuaian adalah jurnal yang dibuat pada akhir periode untuk mengoreksi akun-akun sehingga mencerminkan keadaan yang sebenarnya.

Pada umumnya akun-akun yang perlu penyesuaian di akhir periode seperti:

a. Pendapatan yang diterima di muka dan biaya yang di bayar di muka

b. Biaya pemakaian perlengkapan kantor periode berjalan.

c. Beban penyusutan dan akumulasi penyusutan aktiva tetap

d. Akun-akun lainnya yang membutuhkan penyesuaian di akhir periode.

6. Laporan Keuangan 
Laporan keuangan pokok terdiri dari neraca, laba rugi, dan perubahan kekayaan bersih. Neraca adalah keadaan posisi keuangan pada tanggal tertentu. Laba rugi adalah ikhtisar pendapatan dan biaya untuk jangka waktu tertentu, sedangkan perubahan kekayaan bersih adalah ikhtisar kenaikan dan penurunan kekayaan perusahaan.

Secara umum, laporan keuangan bank syariah dijelaskan sebagai berikut:

1. Laporan keuangan yang menggambarkan fungsi bank islam sebagai investor, hak dan kewajibannya, dengan tidak memandang tujuan bank islam itu dari masalah investasinya, apakah ekonomi atau sosial. Mekanisme investasi yang digunakan terbatas hanya kepada beberapa cara yang diperbolehkan syariah, laporan keuangan meliputi:

d. Laporan posisi keuangan;

e. Laporan laba rugi;

f. Laporan arus kas;

g. Laporan laba ditahan atau laproran perubahan pada saham pemilik.

2. Sebuah laporan keuangan yang menggambarkan perubahan dalam investasi terbatas, yang dikelola oleh bank islam untuk kepentingan masyarakat, baik berdasarkan kontrak mudharabah atau kontrak perwakilan. Laporan semacam ini akan dirujuk sebagai "Laporan Perubahan dalam Investasi Terbatas".

3. Laporan keuangan yang menggambarkan peran bank islam sebagai fiduciary dari dana yang tersedia untuk jasa sosial ketika jasa semacam itu diberikan melalui dana terpisah.

a. Laporan sumber dan pennggunaan dana zakat dan dana social

b. Laporan sumber dan penggunaan dana $\operatorname{qardh}^{28}$.

Berikut disajikan contoh bentuk laporan keuangan bank syariah, sebagai berikut $^{29}$ :

${ }^{28}$ Ibid, h. 235

${ }^{29}$ Ibid, h. 239 
Bentuk laporan keuangan yang disajikan, bukan dimaksudkan untuk menggambarkan satu-satunya metode penyajian dalam laporan keuangan.

1. Laporan posisi keuangan (neraca) bank syariah

\begin{tabular}{|c|c|c|c|}
\hline $\begin{array}{r}\text { Lapora } \\
\mathrm{E}\end{array}$ & $\begin{array}{l}\text { (Nama E } \\
\text { osisi Ke } \\
\text { an xx bu }\end{array}$ & $\begin{array}{l}\text { gan Neraca } \\
\text { gxxx }\end{array}$ & \\
\hline Uraian & Catatan & $\begin{array}{l}\text { Unit moneter } \\
\text { thn berjalan }\end{array}$ & $\begin{array}{l}\text { Unit moneter } \\
\text { tahn lalu }\end{array}$ \\
\hline Aktiva & & & \\
\hline Aktiva Lancar: & & & \\
\hline Kas dan setara kas & & Rp. XXX & Rp. XXX \\
\hline Piutang penjualan & & Rp. XXX & Rp. XXX \\
\hline Investasi: & & & \\
\hline Investasi dalam surat2 berharga & & Rp. XXX & Rp. XXX \\
\hline Investasi mudharabah & & Rp. XXX & Rp. XXX \\
\hline Investasi musyarakah & & Rp. XXX & Rp. XXX \\
\hline Penyertaan modal & & Rp. XXX & Rp. XXX \\
\hline Persediaan & & Rp. XXX & Rp. XXX \\
\hline Investasi pada real estat & & Rp. XXX & Rp. XXX \\
\hline Aktiva yang disewakan & & Rp. XXX & Rp. XXX \\
\hline Istishana & & Rp. XXX & Rp. XXX \\
\hline Investasi lain-lain & & Rp. XXX & Rp. XXX \\
\hline Total investasi & & Rp. XXX & Rp. XXX \\
\hline Aktiva tetap & & Rp. XXX & Rp. XXX \\
\hline Total aktiva & & Rp. XXX & Rp. XXX \\
\hline Passiva & & & \\
\hline $\begin{array}{l}\text { Kewajiban } \\
\text { Rekening Koran dan tabungan }\end{array}$ & & Rp. XXX & Rp. XXX \\
\hline Rek. Koran bank \& lemb. & & Rp. XXX & Rp. XXX \\
\hline Keu.utang & & Rp. XXX & Rp. XXX \\
\hline Deviden yang diusulkan & & Rp. XXX & Rp. XXX \\
\hline Kewajiban lainnya & & & \\
\hline Total Kewajiban & & Rp. XXX & Rp. XXX \\
\hline Ekuitas pemilik & & & \\
\hline Modal disetor & & Rp. XXX & Rp. XXX \\
\hline Cadangan & & Rp. XXX & Rp. XXX \\
\hline Laba ditahan & & Rp. XXX & Rp. XXX \\
\hline $\begin{array}{l}\text { Total Passiva (kewajiban + } \\
\text { ekuitas) }\end{array}$ & & Rp. XXX & Rp. XXX \\
\hline
\end{tabular}

Hasil modifikasi penulis 
2. Laporan Laba Rugi bank syariah

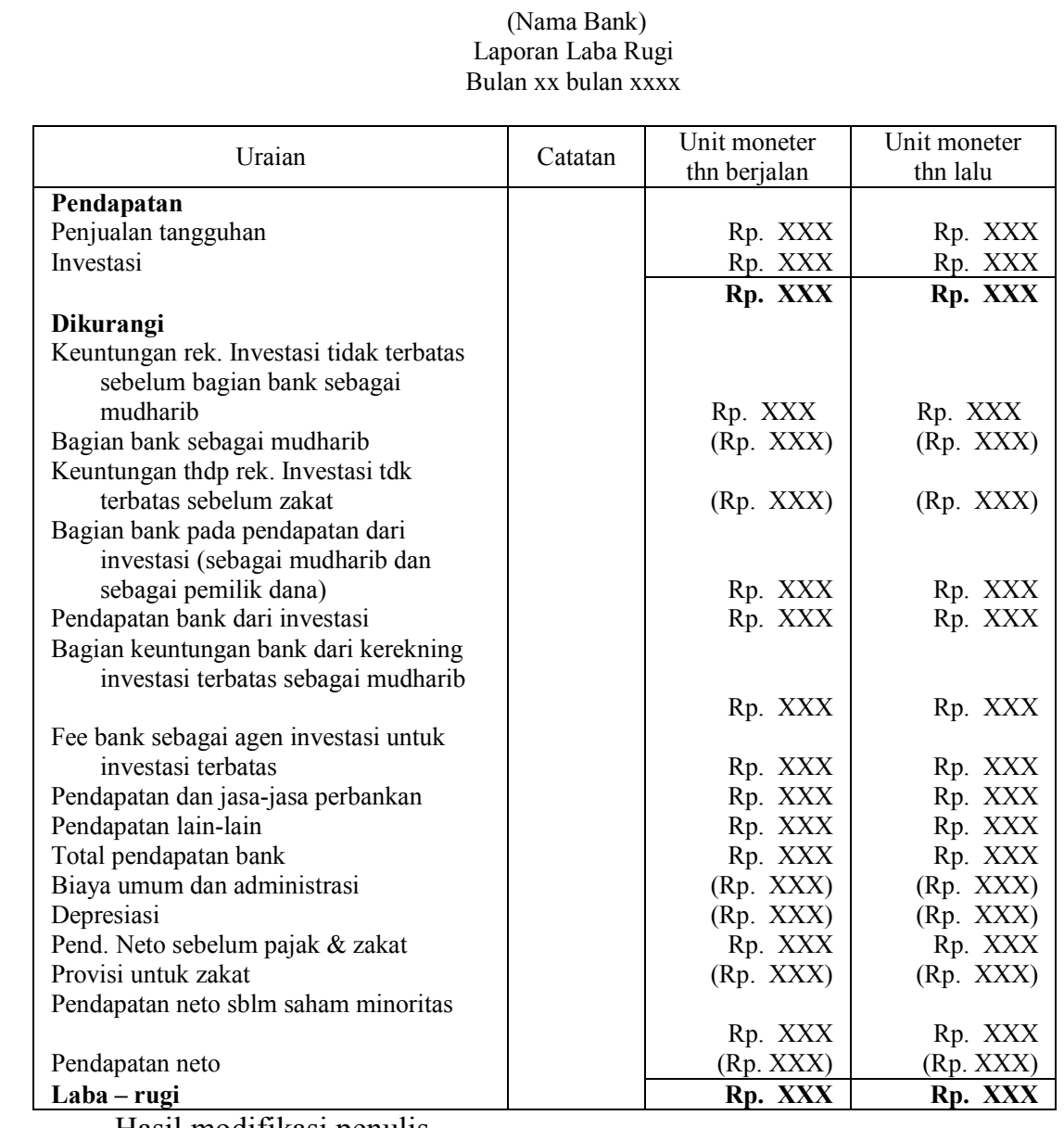

Hasil modifikasi penulis

3. Laporan Perubahan Modal atau Laporan Laba Ditahan Bank syariah

(Nama Bank)

Laporan Perubahan Modal

Bulan $\mathrm{xx}$ bulan $\mathrm{xxxx}$

\begin{tabular}{|c|c|c|c|c|c|}
\hline Uraian & $\begin{array}{l}\text { Modal disetor } \\
\text { unit moneter }\end{array}$ & $\begin{array}{l}\text { Cad. Unit } \\
\text { moneter yg } \\
\text { dah }\end{array}$ & $\begin{array}{c}\text { Unit } \\
\text { moneter } \\
\text { umum }\end{array}$ & $\begin{array}{l}\text { Laba } \\
\text { ditahan }\end{array}$ & total \\
\hline \multirow{9}{*}{$\begin{array}{l}\text { Saldo per xxx (tahun) } \\
\text { Pendapatan neto } \\
\text { Keuntungan dibagikan } \\
\text { Transfer ke cadangan } \\
\text { Neraca per } \\
\quad \text { (xxx(tahun) } \\
\text { Pendapatan neto } \\
\text { Keuntungan dibagikan } \\
\text { Transfer ke cadangan } \\
\text { Saldo per xxx (tahun) }\end{array}$} & XXX.XXX & $=$ & - & - & XXX.XXX \\
\hline & - & - & - & $\mathrm{xxx}$ & $\mathrm{xxx}$ \\
\hline & - & - & - & $(\mathrm{xxx})$ & $(\mathrm{xxx})$ \\
\hline & - & $\mathrm{xxx}$ & $\mathrm{xxx}$ & (xxx) & - \\
\hline & xxx.xxx & $\mathrm{xxx}$ & $\mathrm{xxx}$ & $\mathrm{xxx}$ & xxx.xxx \\
\hline & & & & $\mathrm{xxx}$ & $\mathrm{xxx}$ \\
\hline & & & & $(\mathrm{xxx})$ & $(\mathrm{xxx})$ \\
\hline & & $\mathrm{xxx}$ & $\mathrm{xxx}$ & $\mathrm{xxx}$ & - \\
\hline & $\mathrm{xxx} . \mathrm{xxx}$ & $\mathrm{xxx}$ & $\mathrm{xxx}$ & $\mathrm{xxx}$ & XXX.XXX \\
\hline
\end{tabular}

Hasil modifikasi penulis 
4. Laporan Sumber dan Penggunaan Dana Zakat, Infak, dan Shadaqah Bank Syariah

(Nama Bank)

Laporan Sumber dan Penggunaan

Dana Zakat, Infak, dan Shadaqah Bulan $\mathrm{xx}$ bulan $\mathrm{xxxx}$

\begin{tabular}{|c|c|c|c|}
\hline Uraian & Catatan & $\begin{array}{l}\text { Unit moneter } \\
\text { thn berjalan }\end{array}$ & $\begin{array}{l}\text { Unit moneter } \\
\text { thn lalu }\end{array}$ \\
\hline \multirow{5}{*}{$\begin{array}{l}\text { Sumber-sumber zakat dan sumbangan } \\
\text { Zakat jatuh tempo dari bank } \\
\text { Zakat jatuh tempo dari para pemilik rek. } \\
\text { Sumbangan } \\
\text { Total sumber zakat }\end{array}$} & & & \\
\hline & & $\mathrm{x} . \mathrm{xxx} . \mathrm{xxx}$ & $\mathrm{x} . \mathrm{xxx} \cdot \mathrm{xxx}$ \\
\hline & & $\mathrm{xxx} \cdot \mathrm{xxx}$ & $\mathrm{Xxx} . \mathrm{xxx}$ \\
\hline & & $\mathrm{xxx} \cdot \mathrm{xxx}$ & $\mathrm{xxx} \cdot \mathrm{xxx}$ \\
\hline & & X.XXX.XXX & X.XXX.XXX \\
\hline \multicolumn{4}{|l|}{ Penggunaan Zakat dan Sumbangan } \\
\hline Zakat untuk fakir dan miskin & & $\mathrm{xxx} \cdot \mathrm{xxx}$ & $\mathrm{xxx} \cdot \mathrm{xxx}$ \\
\hline Zakat untuk Ibnu sabil & & $\mathrm{xxx} \cdot \mathrm{xxx}$ & $\mathrm{xxx} \cdot \mathrm{xxx}$ \\
\hline Zakat untuk mu'allaf & & $\mathrm{xxx} \cdot \mathrm{xxx}$ & $\mathrm{xxx} . \mathrm{xxx}$ \\
\hline Zakat untuk fisabilillah & & $\mathrm{xxx} \cdot \mathrm{xxx}$ & $\mathrm{xxx} \cdot \mathrm{xxx}$ \\
\hline Zakat untuk amil zakat (by.Adm. \& umum & & $\mathrm{xxx} \cdot \mathrm{xxx}$ & $\mathrm{xxx} \cdot \mathrm{xxx}$ \\
\hline Total penggunaan dana & & X.XXX.XXX & X.XXX.XXX \\
\hline $\begin{array}{c}\text { Kenaikan/penurunan sumber terhadap } \\
\text { penggunaan }\end{array}$ & & $\mathrm{x} . \mathrm{Xxx} \cdot \mathrm{xxx}$ & X.XXX.XXx \\
\hline $\begin{array}{l}\text { Zakat dan sumbangan yang belum dibagikan } \\
\text { pada awal tahun }\end{array}$ & & $\mathrm{X} \cdot \mathrm{xxx} \cdot \mathrm{xxx}$ & X.Xxx.Xxx \\
\hline $\begin{array}{l}\text { Zakat dan sumbangan yang belum dibagikan } \\
\text { pada akhir tahun }\end{array}$ & & $\mathrm{x} . \mathrm{XxX} \cdot \mathrm{xxx}$ & X.XXX.XXx \\
\hline
\end{tabular}

Hasil modifikasi penulis

ii. Laporan Sumber dan Penggunaan Dana Qardahul Hasan Bank Syariah

(Nama Bank)

Laporan Sumber dan Penggunaan Dana Qardahul Hasan

Bulan xx bulan xxxx

\begin{tabular}{|c|c|c|c|}
\hline Uraian & Catatan & $\begin{array}{l}\text { Unit moneter } \\
\text { thn berjalan }\end{array}$ & $\begin{array}{l}\text { Unit moneter } \\
\text { thn lalu }\end{array}$ \\
\hline \multicolumn{4}{|l|}{ Saldo awal } \\
\hline Pinjaman kebaikan & & $\mathrm{xxx} \cdot \mathrm{xxx}$ & $\mathrm{xxx} \cdot \mathrm{xxx}$ \\
\hline Sumber-sumber dana qardahul hasan & & $\mathrm{xxx} . \mathrm{xxx}$ & $\mathrm{xxx} \cdot \mathrm{xxx}$ \\
\hline Alokasi dari rekening koran & & $\mathrm{xxx} \cdot \mathrm{xxx}$ & $\mathrm{xxx} \cdot \mathrm{xxx}$ \\
\hline Alokasi pend. Yg dilarang syariah (haram) & & $\mathrm{xxx} \cdot \mathrm{xxx}$ & $\mathrm{xxx} \cdot \mathrm{xxx}$ \\
\hline Sumber diluar bank & & $\mathrm{xxx} \cdot \mathrm{xxx}$ & $\mathrm{xxx} \cdot \mathrm{xxx}$ \\
\hline Total sumber dana selama tahun berjalan & & xxx.xxx & Xxx.xxx \\
\hline \multicolumn{4}{|l|}{ Penggunaan Oardahul Hasan } \\
\hline \multicolumn{4}{|l|}{ Pinjaman kpd para pelajar } \\
\hline \multicolumn{4}{|l|}{ Pinjaman kpd para pengrajin } \\
\hline \multirow{2}{*}{$\begin{array}{l}\text { Penyelesaian rekening koran } \\
\text { Total penggunaan dana selama tahun berjalan }\end{array}$} & & $\mathrm{xxx} \cdot \mathrm{xxx}$ & $\mathrm{xxx} \cdot \mathrm{xxx}$ \\
\hline & & xxx.xxx & xxx.xxx \\
\hline \multicolumn{4}{|l|}{ Saldo akhir tahun } \\
\hline Pinjaman kebajikan & & $\mathrm{xxx} . \mathrm{xxx}$ & $\mathrm{xxx} . \mathrm{xxx}$ \\
\hline Dana tersedia untuk pinjaman & & xxx.xxx & $\mathrm{xxx} . \mathrm{xxx}$ \\
\hline
\end{tabular}

Hasil modifikasi penulis 


\section{g. Kesimpulan}

Pada sistem operasi bank syariah, pemilik dana menanamkan uangnya di bank syariah tidak dengan motif mendapatkan bunga, tapi dalam rangkah keuntungan bagi hasi sesuai dengan kesepakatan, dengan konsep dan prinsip yang dianut bank syariah perinsip dan konsep bank syariah perjanjian, dana yang dihimpun melalui produk penghimpunan dana yang terdiri dari prinsip wadi'ah dan prinsip mudharabah, sedangkan dana disalurkan melalui produk yang terdiri murabahah, bai'As-salam, al-istishnana, musyarakah.

Kualitas bank syariah sebagai lembaga perantara ditentukan kemampuan manajemen dalam operasinya serta penyajian dalam akuntansinya yang tidak bertentangan dengan prinsip-prinsip muamalah. Penyajian dalam laporan akuntansi bank syariah harus mampu menfasilitasi semua pihak yang terikat dengan bank syariah yakni laporan posisi keuangan/neraca, laporan laba rugi, Laporan arus kas, laporan laba ditahan atau laproran perubahan pada saham pemilik, laporan perubahan dalam investasi terbatas, laporan sumber dan pennggunaan dana zakat dan dana social, laporan sumber dan penggunaan dana qardh.

\section{h. Daftar Pustaka}

Ali, Hasyim, Manajemen Bank Islam. Jakarta: Radar Jaya Offset, 1992.

Anonimus, Prodak-prodak Bank Islam. Jakarta: Karim Consulting bekerjasama dengan Bank Indonesia, 20020, dalam Muhammad Syafii Antonio, Bank Syariah dari Teori ke Praktitik. Jakarta: Gema Insani, 2001.

Donna, Duddy Roesmara, Variabel-variabel yang Mempengaruhi Pembiayaan Perbankan Syariah di Indonesia. Tesis. Yogyakart, FE UGM, 2006.

Hall, James, A., Sistem Informasi Akuntansi. Jakarta: Penerbit Salemba Empat edisi ke 4, 2007

Ikatan Akuntansi Indonesia, Standar Akuntansi Keuangan No. 59 Revisi tahun 2004. Jakarta. PT Salemba Empat, 2004.

La Midjan, Sistem Informasi, Pendekatan Manual Praktika Penyusunan Metode dan Prosedur. Bandung: Penerbit Binanyanti, edisi IX, 1995 
Muhammad Ibn Ahmad Ibnu Rusyd, Bidayatul Nutjihad wa Nihayatul Mugtashid Darul Qalam, dalam Muhammad Syaii Antoni, Bank Syariah dari Teori ke Praktik. Jakarta: Penerbit: Gema Insani, 2001.

Muhammad Syafii Antonio, Bank Syariah dari Teori ke Praktitik Jakarta: Gema Insani, 2001.

, Bank Syariah. Jakarta: PT Serambi Ilmu Persada, 2002

, Pengenalan Umum Bank Syariah. Jakarta: Tazkia Institut bekerja sama dengan Bank Indonesia, 1999.

Muhammad, Pengantar Akuntansi Syariah, Jakarta: Salemba Empat, Edisi 2, 2005.

Lembaga Keuangan Umat Kontemporer, dalam Muhammad, Pengantar Akuntuntasi Syariah edisi 2, Yogyakarta: Penerbit Salemba Empat, 2005.

Lembaga Keuangan Umat Kontemporer, Yogyakarta: Penerbit UII Press, 2000.

system dan Prosedur Bank Syariah, Yogyakarta: Penerbit UII Press, 2000, dalam Muhammad, Pengantar Akuntansi Syariah. Jakarta: Salemba Empat, 2005.

Sayyid Sabiq, Fighus Sunnah. Beirut: Darul Kitab al-Arabi, cetakan 8, 1987, h. 3, dalam Muhammad Syafii Antonio, Bank Syariah dari Teori ke Praktitik Jakarta: Gema Insani, 2001.

Sudarsono, H., Bank dan lembaga Keuangan Syariah Deskrpsi dan Ilustrasi. Yogyakarta: Penerbit Ekonisia, 2004.

http://bi.go.id. organisasi.org/macam-jenis-bank-definisi-pengertian-bank, dalam 20 Feb. 2010. 